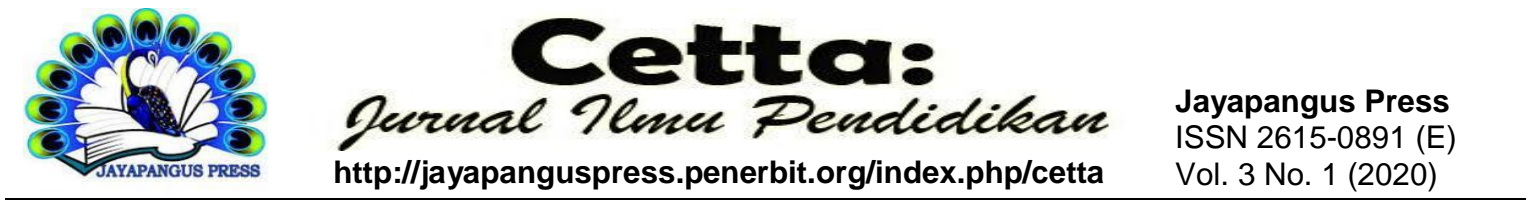

\title{
Implementasi Model Pendidikan Lingkungan UNESCO Di Sekolah Dasar
}

\author{
Ni Kadek Supadmini ${ }^{1}$, I Komang Wisnu Budi Wijaya ${ }^{2}$, Ida Ayu Diah Larashanti ${ }^{3}$ \\ Institut Hindu Dharma Negeri Denpasar \\ 1ayutrisnadewimaheswari@gmail.com, 2wisnu.budiwijaya240191@gmail.com, \\ 3diahlarasanti20@gmail.com
}

DOI : $10.37329 /$ cetta.v3i1.416

\begin{tabular}{ll}
\hline Keywords: & Abstract \\
\cline { 2 - 3 } $\begin{array}{l}\text { Education, } \\
\text { Environment, }\end{array}$ & $\begin{array}{l}\text { Human and the environment have an interdependence relationship. The } \\
\text { UNESCO, }\end{array}$ \\
Primary School & versa. In fact, the degradation of environmental quality is mostly happen \\
& due to human activities. Therefore, it is necessary to apply the \\
& environmental education since primary school age. UNESCO has \\
& developed the environmental education model consists of three \\
& conceptual, they are education about the environment, education in the \\
& environment and education for the environment. This UNESCO \\
& environmental education development model is suitable to be applied in \\
& primary school for inside or outside classroom activities. The teacher's \\
& role in implementing the environmental education model is as a model, \\
motivator, developer and evaluator.
\end{tabular}

\begin{tabular}{l}
\hline Kata Kunci: \\
\hline Pendidikan, \\
Lingkungan, \\
UNESCO, Sekolah \\
Dasar
\end{tabular}

\begin{tabular}{l} 
Abstrak \\
\hline Manusia dan lingkungan memiliki hubungan saling \\
ketergantungan. Kelangsungan hidup manusia bergantung dari \\
kondisi lingkungan dan demikian pula sebaliknya. Faktanya, \\
penurunan kualitas lingkungan sering terjadi yang sebagian \\
besar disebabkan oleh ulah manusia. Dengan demikian, perlu \\
ditanamkan pendidikan lingkungan kepada manusia sejak usia \\
sekolah dasar. UNESCO telah mengembangkan model \\
pendidikan lingkungan yang terdiri dari tiga wahana konseptual \\
yaitu pendidikan tentang lingkungan (education about \\
environment), pendidikan di dalam lingkungan (education in \\
environment) dan pendidikan untuk lingkungan (education for \\
environment). Model pengembangan pendidikan lingkungan \\
UNESCO ini cocok diterapkan di sekolah dasar dalam kegiatan \\
pembelajaran di kelas dan di luar kelas. Peran guru dalam \\
implementasi model pendidikan lingkungan adalah sebagai \\
teladan, motivator, pengembang dan penilai.
\end{tabular}




\section{Pendahuluan}

Manusia dan lingkungan adalah dua hal yang saling ketergantungan. Kelangsungan hidup manusia sangat bergantung dengan kondisi lingkungan dan eksistensi lingkungan sangat bergantung pada cara manusia memperlakukan lingkungan. Dalam ajaran Hindu dikenal sebuah konsep yang sangat populer yaitu Tri Hita Karana. Tri Hita Karana berarti tiga hal yang menyebabkan manusia dapat hidup bahagia. Ketiga hal tersebut adalah hubungan harmonis dengan Tuhan Yang Maha Esa (Parahyangan), hubungan harmonis dengan sesama manusia (Pawongan) dan hubungan harmonis dengan lingkungan (Palemahan). Ketiga hal tersebut hendaknya dilaksanakan dengan selaras, serasi dan seimbang (Wijaya, 2019).

Fakta yang terjadi saat ini adalah lingkungan hidup manusia telah mengalami penurunan kualitas sehingga mengancam kelangsungan hidup manusia. Penurunan kualitas lingkungan tersebut sebagian besar disebabkan oleh ulah manusia yang tidak bertanggung jawab. Pencemaran air, udara, tanah, perubahan iklim, deforesitasi dan tanah longsor merupakan beberapa contoh penurunan kualitas lingkungan yang disebabkan oleh manusia.

Eksistensi lingkungan hidup harus dijaga dari kerusakan agar kelangsungan hidup manusia dan ekosistem lainnya tetap ajeg. Jika dikaji lebih mendalam, tindakan manusia yang merusak lingkungan tersebut lebih disebabkan kurangnya pemahaman manusia tentang lingkungan dan rendahnya komitmen manusia untuk menyelesaikan masalah lingkungan (Sahabuddin,2015). Oleh karena itu, diperlukan sebuah upaya untuk meningkatkan pemahaman manusia tentang lingkungan dan membangun sikap positif terhadap lingkungan.

Proses membangun pemahaman manusia tentang lingkungan dan membentuk sikap positif terhadap lingkungan dapat dilakukan melalui pendidikan lingkungan. Pendidikan lingkungan merupakan pembelajaran yang dilakukan untuk membantu peserta didik dalam memahami lingkungan hidup dengan tujuan akhir untuk meningkatkan perlindungan dan sikap bertanggung jawab terhadap lingkungan hidup (Hayati, 2008). UNESCO mengembangkan model pendidikan lingkungan dengan tiga wahana konseptual yaitu pendidikan tentang lingkungan (education about environment), pendidikan di dalam lingkungan (education in environment) dan pendidikan untuk lingkungan (education for environment) (Prasetyo, 2017). Pelaksanaan pendidikan lingkungan hendaknya sudah mulai dilakukan sejak anak memasuki sekolah dasar. Hal 
itu disebabkan pada usia sekolah dasar. Hal ini dikarenakan pada usia sekolah dasar, anak sedang mengalami perkembangan kognitif, sikap dan psikomotor yang sangat pesat (Wijaya, 2018).

\section{Metode}

Metode yang digunakan dalam penulisan jurnal adalah metode studi kepustakaan. Studi kepustakaan berkaitan dengan kajian teoritis dan referensi lain yang berkaitan dengan nilai, budaya dan norma yang berkembang pada situasi sosial yang diteliti (Sugiyono, 2010). Penulis menggunakan berbagai literatur tentang pendidikan lingkungan, karakteristik siswa sekolah dasar dan peran guru dalam pendidikan. Setelah literatur terkumpul lalu dilanjutkan dengan proses analisis serta diolah supaya ringkas dan sistematis. Dalam penelitian ini menggunakan teknik analisis berupa analisis isi (content analysis). Analisis isi merupakn analis ilmiah tentang isi pesan suatu data atau literature.

\section{Hasil dan Pembahasan}

\section{Pendidikan Lingkungan}

Pendidikan lingkungan adalah bahan kajian dan materi tentang lingkungan hidup dalam konteks internalisasi secara langsung maupun tidak langsung dalam membentuk kepribadian mandiri serta pola tindak dan pola pikir siswa dan dapat diimplementasikan dalam kehidupan sehari-hari (Umam, 2018). Prinsip dari pendidikan lingkungan adalah : 1) pendekatan studi yang berorientasi lokal dan global secara integratif 2) focus terhadap dunia dalam perspektif lingkungan yang menyerap perspektif secara komprehensif, 3) pendidikan sebagai landasan pengembangan perilaku bertanggung jawab terhadap lingkungan, 4) focus terhadap pendekatan interdisipliner untuk meningkatkan pemahaman terhadap isu-isu utama dalam mengintegrasikan perspektif lingkungan dah 5) pelaksanaan cooperative learning untuk meningkatkan pemahaman pluralistik dalam masyarakat (Hayati, 2008).

Pendidikan lingkungan hidup di Indonesia telah dilaksanakan sejak tahun 1975, dimulai oleh IKIP Jakarta dengan membuat GBPP bidang lingkungan hidup untuk pendidikan dasar yang kemudian pada tahun ajaran 1977/1978 dilakukan uji coba di 15 sekolah dasar. Perkembangan selanjutnya PLH pada tahun 1996 ditetapkan Memorandum Bersama antara Departemen Pendidikan dan Kebudayaan dengan Kantor 
Menteri Negara Lingkungan Hidup No. 0142/U/1996 dan No Kep: 89/MENLH/5/1996 tentang Pembinaan dan Pengembangan Pendidikan Lingkungan Hidup, tanggal 21 Mei 1996. Sejalan dengan itu, Direktorat Jenderal Pendidikan Dasar dan Menengah (Dikdasmen) Depdikbud juga terus mendorong pengembangan dan pemantapan pelaksanaan pendidikan lingkungan hidup di sekolah-sekolah antara lain melalui penataran guru, penggalakkan bulan bakti lingkungan, penyiapan Buku Pedoman Pelaksanaan Pendidikan Kependudukan dan Lingkungan Hidup (PKLH) untuk Guru SD, SLTP, SMU dan SMK, program sekolah asri, dan lain-lain. LSM dan perguruan tinggi terus mendukung dan membantu dalam dalam mengembangkan PLH melalui kegiatan seminar, sarasehan, lokakarya, penataran guru, pengembangan sarana pendidikan seperti penyusunan modul-modul integrasi, buku-buku bacaan dan lain-lain (TimMKU, 2014).

Tujuan dari pendidikan lingkungan adalah untuk mendorong dan memberikan kesempatan kepada masyarakat memperoleh pengetahuan, keterampilan dan sikap yang pada akhirnya dapat menumbuhkan kepedulian, komitmen untuk melindungi, memperbaiki serta memanfaatkan lingkungan hidup secara bijaksana Sasaran dari pendidikan lingkungan yaitu : 1) terlaksananya pendidikan lingkungan di lapangan sehingga dapat tercipta kepedulian dan komitmen masyarakat dalam turut melindungi, melestarikan dan meningkatkan kualitas lingkungan hidup dan 2) diarahkan untuk seluruh kelompok masyarakat, baik di pedesaan dan perkotaan, tua dan muda, laki-laki dan perempuan di seluruh wilayah Indonesia sehingga tujuan PLH bagi seluruh rakyat Indonesia dapat terwujud dengan baik (Sudjoko, 2014).

Pada tahun 1992, UNESCO telah mengembangkan model pendidikan lingkungan. Model tersebut terdiri dari tiga wahana konseptual yaitu pendidikan tentang lingkungan (education about environment), pendidikan di dalam lingkungan (education in environment) dan pendidikan untuk lingkungan (education for environment) (Prasetyo, 2017). Penjelasan dari ketiga wahana tersebut adalah sebagai berikut :

a. Pendidikan tentang lingkungan memiliki tujuan untuk mengembangkan pengetahuan dan pemahaman kepada siswa tentang sistem alami, fisik dan sosial yang membangun lingkungan.

b. Pendidikan untuk lingkungan bertujuan untuk mengembangkan sikap peserta didik untuk peduli lingkungan, berkarya untuk memperbaiki lingkungan serta menumbuhkembangkan sikap dan nilai positif terhadap lingkungan. 
c. Pendidikan lingkungan adalah proses pendidikan untuk memanfaatkan lingkungan sebagai sumber daya pembelajaran. Ini adalah sumber daya yang mampu mengembangkan sejumlah besar pengetahuan seperti halnya mengembangkan keterampilan dalam menyelidiki dan berkomunikasi.

\section{Implementasi Pendidikan Lingkungan Menurut UNESCO}

Model pendidikan lingkungan menurut UNESCO dapat diterapkan di sekolah dasar. Penerapan model pendidikan lingkungan menurut UNESCO dapat dilakukan dalam pembelajaran di dalam kelas dan di luar kelas. Dalam penerapannya harus mempertimbangkan beberapa hal seperti tujuan dan sasaran, sarana prasarana, karakteristik peserta didik, kesiapan guru serta efektif dan efisiensi. Penerapan model pendidikan lingkungan menurut UNESCO dalam jenjang sekolah dasar disajikan dalam Tabel 1 berikut.

Tabel 1 Implementasi Model Pendidikan Lingkungan UNESCO

\begin{tabular}{|c|c|c|}
\hline No & Dimensi & Implementasi \\
\hline 1 & $\begin{array}{l}\text { Pendidikan tentang } \\
\text { lingkungan }\end{array}$ & $\begin{array}{l}\text { - Menyediakan sumber bacaan tentang lingkungan } \\
\text { - Mang memadai untuk siswa sekolah dasar. } \\
\text { - Menerapkan model pembelajaran berpusat siswa } \\
\text { (student centered) dalam menjelaskan tema dan } \\
\text { subtema yang berkaitan dengan lingkungan. } \\
\text { - Mengadakan seminar atau pelatihan tentang } \\
\text { lingkungan dengan menghadirkan narasumber yang } \\
\text { kompeten di bidang lingkungan. } \\
\text { - Menyediakan poster atau sejenisnya yang berisikan } \\
\text { tentang perkembangan kondisi lingkungan global saat ini. }\end{array}$ \\
\hline 2 & $\begin{array}{l}\text { Pendidikan untuk } \\
\text { lingkungan }\end{array}$ & $\begin{array}{l}\text { - Membudayakan membuang sampah pada tempatnya } \\
\text { - Membudayakan memilah sampah berdasarkan } \\
\text { jenisnya } \\
\text { - Membudayakan hidup bersih dan sehat } \\
\text { - Mengajak siswa untuk berpartisipasi aktif dalam } \\
\text { kegiatan penyelamatan lingkungan misalnya } \\
\text { menanam pohon perindang, membersihkan selokan } \\
\text { yang tersumbat dan kegiatan lainnya. }\end{array}$ \\
\hline
\end{tabular}




\begin{tabular}{|c|c|c|}
\hline & & $\begin{array}{l}\text { - Memberikan pembinaan kepada siswa yang apatis } \\
\text { terhadap lingkungan } \\
\text { - Mengadakan lomba yang berkaitan lingkungan di } \\
\text { waktu tertentu misalnya lomba kebersihan kelas, } \\
\text { kebersihan halaman dan lomba lain yang berkaitan. }\end{array}$ \\
\hline 3 & $\begin{array}{l}\text { Pendidikan di } \\
\text { lingkungan }\end{array}$ & $\begin{array}{l}\text { - Mengajak siswa untuk belajar di luar kelas, misalnya } \\
\text { di taman sekolah jika menyajikan materi yang } \\
\text { berkaitan dengan lingkungan. } \\
\text { - Mengajak siswa untuk melihat langsung contoh } \\
\text { lingkungan yang sehat dan tercemar }\end{array}$ \\
\hline
\end{tabular}

\section{Peran Guru dalam Implementasi Pendidikan Lingkungan}

Keberadaan guru dalam proses pendidikan sangatlah vital termasuk dalam pendidikan lingkungan. Peran guru dalam implementasi pendidikan lingkungan versi UNESCO adalah berikut :

a. Sebagai pengembang. Peran guru sebagai pengembang adalah guru dituntut mampu mengembangkan model pendidikan lingkungan UNESCO di sekolah dengan memperhatikan kesiapan guru, sarana prasarana dan karakteristik peserta didik.

b. Sebagai teladan. Guru harus mampu memberikan contoh sikap-sikap positif terhadap lingkungan dalam kehidupan sehari-hari sehingga bisa ditiru oleh siswanya.

c. Sebagai motivator. Guru berperan untuk memberikan dukungan dan semangat kepada siswanya dalam proses implementasi pendidikan lingkungan di sekolah.

d. Sebagai evaluator. Guru nantinya melakukan evaluasi terhadap implementasi pendidikan lingkungan yang telah dilakukan. Hasil evaluasi itu nantinya akan dijadikan bahan refleksi dan tindak lanjut untuk periode berikutnya.

\section{Kesimpulan}

Pendidikan lingkungan menjadi sesuatu yang mendesak untuk diterapkan di lingkungan sekolah khususnya sekolah dasar. Hal itu disebabkan kerusakan lingkungan yang semakin parah di setiap harinya dan kelangsungan hidup manusia sangat bergantung dari kondisi lingkungan. Model pendidikan lingkungan menurut UNESCO nampaknya cocok direkomendasikan untuk diterapkan dalam lingkungan sekolah dasar. 
Model tersebut sudah mencakup aspek kognitif, afektif dan psikomotor. Model pendidikan lingkungan menurut UNESCO bisa diterapkan dalam kegiatan pembelajaran dan di luar kegiatan pembelajaran. Dalam penerapannya membutuhkan peran vital guru sebagai pengembang, teladan, motivator dan evaluator.

\section{Daftar Pustaka}

Hayati, S. (2008). Pendidikan Lingkungan Hidup dalam Membentuk Perilaku Lingkungan Bertanggung Jawab. Bandung.

Prasetyo, K. (2017). Pendidikan Lingkungan Indonesia, Dasar Pedagogi dan Metodologi. Bandung: PT. Remaja Rosdakarya.

Sahabuddin, E. S. (2015). MODEL PEMBELAJARAN PENDIDIKAN LINGKUNGAN HIDUP BERBASIS EDUCATIONAL-PORTOFOLIO SUATU TINJAUAN. Prosiding Seminar Nasional 2015 Lembaga Penelitian UNM, 95-114.

Sudjoko. (2014). Perkembangan dan Konsep Dasar Pendidikan Lingkungan Hidup. In Pendidikan Lingkungan Hidup. Jakarta: Universitas Terbuka.

Sugiyono. (2010). Metode Penelitian Pendidikan Pendekatan Kuantitatif, Kualitatif dan RED. Bandung: Penerbit Alfabeta.

TimMKU. (2014). Pendidikan Lingkungan Hidup. Semarang: Universitas Negeri Semarang.

Umam, K. (2018). Implementasi Pendidikan Lingkungan Hidup Pada Sekolah Adiwiyata Mandiri SDN Dinoyo 2 Kota Malang. UIN Maulana Malik Ibrahim Malang.

Wijaya, I. K. W. B. (2018). MENGEMBANGKAN KECERDASAN MAJEMUK SISWA SEKOLAH DASAR (SD) MELALUI PEMBELAJARAN IPA UNTUK MENINGKATKAN MUTU LULUSAN SEKOLAH DASAR. Jurnal Penjaminan Mutu, $4,147-154$.

Wijaya, I. K. W. B. (2019). ECO FAMILY: METODE PARENTING ANAK USIA DINI UNTUK MEMBENTUK GENERASI LITERASI LINGKUNGAN. Jurnal Pratama Widya, 4, 40-47. 